\title{
The onset of English lexical acquisition among Malaysian preschoolers
}

\section{Rabiah Tul Adawiyah Mohamed Salleh, Bruno Di Biase \& Satomi Kawaguchi}

To cite this article: Rabiah Tul Adawiyah Mohamed Salleh, Bruno Di Biase \& Satomi Kawaguchi (2022): The onset of English lexical acquisition among Malaysian preschoolers, Journal of Multilingual and Multicultural Development, DOI: 10.1080/01434632.2022.2041022

To link to this article: https://doi.org/10.1080/01434632.2022.2041022

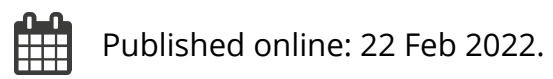

Submit your article to this journal $\longleftarrow$

Q View related articles ๘

View Crossmark data ¿ 


\title{
The onset of English lexical acquisition among Malaysian preschoolers
}

\author{
Rabiah Tul Adawiyah Mohamed Salleh ${ }^{a}$, Bruno Di Biase ${ }^{b}$ and Satomi Kawaguchi ${ }^{b}$ \\ ${ }^{a}$ Department of English Language and Literature, International Islamic University, Kuala Lumpur, Malaysia; \\ bilingualism Research Lab, Western Sydney University, Milpera, Australia
}

\begin{abstract}
English is undoubtedly an important language for educational and socioeconomic mobility in numerous countries including Malaysia. Regardless of its importance, studies to document English language acquisition among Malaysian children acquiring English in the local context remain scarce. This normative data is imperative for syllabus-designers, policymakers, teachers and linguists to understand and to develop materials that are developmentally sensitive and contextualised to the local setting. Thus, the objective of this paper is to present the onset of English lexical acquisition among 99 Malaysian preschoolers at the beginning of formal instruction. The 99 children were pupils in 3 public preschools in Klang Valley, Malaysia. The children's language production was elicited in individual communicative tasks. Their lexical output, both in English and Malay were analysed based on the children's language choice during the session as well as the frequencies of types and tokens. The results indicate that Malaysian preschoolers displayed a limited range of productive abilities and age-sensitive vocabulary in English at the beginning of formal instruction. However, at that point, the children already possess receptive skills greater than their productive skills. Based on the findings, implications for pedagogy are also discussed.
\end{abstract}

\author{
ARTICLE HISTORY \\ Received 3 June 2021 \\ Accepted 3 February 2022

\section{KEYWORDS} \\ English as a second \\ language; lexical \\ development; Malaysian \\ preschoolers
}

\section{Introduction}

Malaysia is a post-colonial nation in Southeast Asia and home to diverse ethnic communities, such as Malays, Chinese, Indians and other indigenous sub-communities. Naturally, the diversity of the society leads to multilingualism. Due to its role as the medium of interaction between its multi-ethnic communities, Bahasa Melayu (Malay language) is established as the national language in 1967 (Gill 2014). Malay is the first language of the Malay ethnic community; while for the other communities, Malay is considered as their second language (Ahmad 2005). Other languages are also widely spoken by the respective community in Malaysia, including Mandarin, Cantonese, Hakka, Tamil, Telegu, Malayalam, Punjabi, Hindi, and many other minority languages (Gill 2014). Despite the complex linguistic tapestry, the English language plays a vital role in educational endeavours, governance and popular culture. Due to globalisation, English is highly regarded as a tool and vehicle for international communication and upward mobility. Realising the importance of English, the Malaysian government has included English proficiency as one of the aspirations to further transform the educational system. This is reflected in Malaysia Education Blueprint (2013-2025); 
bilingual proficiency in Malay and English is the Second Shift (Shift 2) among the 11 shifts outlined by the Ministry of Education (2013).

Malaysia, then, turns out to be of considerable linguistic interest to researchers due to the existence of many first languages, together with its emphasis on English in its educational setting. However, despite the importance of English, studies investigating learners' development, particularly young learners acquiring English in the Malaysian context, are less than plentiful. An extensive search of the literature reveals that there is a limited resource to determine the milestones and normative development for English language acquisition among Malaysian children. Yet, information about English milestone development, which is contextualised to the Malaysian setting and experience is fundamental for educators, syllabus-designers, researchers and speech-language pathologists. To understand English acquisition among Malaysian children, their development requires to be investigated and evaluated on its own merit, which includes the circumstances surrounding the bilingual and multilingual environment the children are in. The current language learning environments of Malaysian children should not be compared to the traditional monolingual English-dominant environment which has been reported in many child language acquisition studies.

Studies investigating learners' language development at the school level are necessary because English, in Malaysia, is generally acquired through formal instruction, that is through school experience (Azman 2009). However, it is not known what the level of English is, particularly the vocabulary, that Malaysian children may already possess at the beginning of their education. According to Wilkins (1972), lexicon/vocabulary is the foundation of early language learning. As similarly envisaged in lexicalist models of grammar such as Kaplan and Bresnan (1982) and Bresnan (2001) the lexicon is the component that drives the construction of grammar. Several empirical studies have also shown that the size of children's vocabulary is strongly correlated with their grammatical development (Marchman and Bates 1994; Moyle et al. 2007; Sansavini et al. 2006). Given these premises, this study aims to address the described gap by presenting an investigation of the acquisition of English lexical forms among Malaysian preschoolers at the onset of formal instruction. This study is part of a longitudinal investigation into the acquisition of English lexicon and morphology among Malaysian preschoolers. The following research question guided the investigation:

What English lexical forms do Malaysian preschoolers produce at the beginning of formal instruction?

In what follows, a review of preschool education in Malaysia will be presented, followed by earlier studies conducted on Malaysian preschool children. This will be followed by the methodology section with details on the participants, data collection and data analytical procedures. In the latter part of the paper, the results and discussion from the investigation are presented and discussed. The paper concludes with a summary of the findings and the limitation of the study.

\section{Preschool and English language education in Malaysia}

In Malaysia, the public preschools are divided into several types: (a) KEMAS preschools under the Ministry of Rural and Regional Development, which was first established in the 1970s (b) PERPADUAN preschools under the Department of National Unity, also established in the 1970s (c) MOE preschools under the governance of the Ministry of Education, first set up in 1992. There are also JAIN preschools under the purview of the State Religious Department and ABIM preschools under the Angkatan Belia Islam Malaysia (ABIM), a non-government organisation (Mustafa and Azman 2013). Preschools under the governance of MOE are further divided into two types; (a) national MOE preschools, which use Malay as the medium of instruction (b) national-type or vernacular MOE preschools, which use Mandarin or Tamil as the medium of instruction. For the national MOE preschools, Malay and English are equally allocated 600 minutes each week as the medium of instructions. For the national-type/vernacular MOE preschools, equal instruction time is divided between Mandarin or Tamil (400 minutes), Malay (400 minutes) and English (400 minutes). 
Given the various types of preschools in Malaysia, the Ministry of Education (henceforth MOE) has set standardised guidelines for all preschools, both public and private, to follow. This is the National Standard Preschool Curriculum (henceforth NSPC) first issued by MOE in 2010 and revised in 2016 (Ministry of Education 2016). There are six components in NSPC: Communications, Spirituality, Attitude and Values, Humanity, Self-Esteem, Physical and Aesthetics, and Science and Technology. NSPC closely follows the shifts outlined in the Malaysia Education blueprint (2013-2025). Proficiency in Malay and English and other languages is part of the Communication component in NSPC. Thus, in general, Malaysian 4-6 years old children are introduced to the English language at the preschool level. English continues to be taught as a compulsory subject at primary school (7-12 years old), secondary school (13-17 years old) and tertiary education (Azman 2016).

As a developing nation, English language proficiency is highly regarded as a desirable attribute for economic and social mobility at the national as well as international level. Hence, English language education has always been the focus of several educational reforms by the government from pre-independence days until the current times (see Gill 2014 for a comprehensive review of Malaysia's language policy in education). However, it has been reported in many published studies that despite the many educational reforms, English proficiency and communication skills of Malaysian students are reported as being generally below expectation, considering that English formal instruction continues from kindergarten up till the tertiary level, i.e. for at least 11 consecutive years (Che Musa, Khoo, and Azman 2012; Gill 2014; Pandian 2002; Sulaiman, Mohd Ayub, and Sulaiman 2015).

Based on extensive literature search, we found that studies on English language acquisition in the Malaysian context have been mainly carried out on Malaysian tertiary learners and graduates (e.g. Isai et al. 2020; Mohd Zin, Eng, and Rafik-Galea 2014; Sarudin et al. 2013; Ting et al. 2017; Turiman, Abdullah, and Mohd Noor 2018; Zainuddin et al. 2018). We posit that to understand the underlying cause of Malaysian learners' English performance, studies investigating learners' development at the earlier level, such as at the preschool levels, are necessary. Language development, then, should be traced back to the onset of acquisition - which in Malaysia generally means at the preschool level. The following section describes some studies related to language acquisition among Malaysian young learners.

\section{Language acquisition studies on Malaysian children}

Currently, there seems to be a paucity of studies exploring Malay L1 development. One prominent study is by Razak et al. (2016); the authors profiled Malay L1 children's syntactic development and from the data, they developed the first standardised language test in Malaysia, i.e. the Malay Language Assessment, Remediation and Screening Procedure (Malay LARSP). In a comprehensive review by Razak (2014), it was found that past acquisition research in Malay L1 (e.g. Omar 1988; Simanjutak 1990; Mohamad Noor 2002; Arshad and Subramaniam 2006) has been sporadic and involved mainly case studies of a small number of participants. This leads to the difficulty of establishing normative data for Malay L1 children's language development.

Pertaining to English L2 development, there are some relatively recent studies that investigated the English lexical learning among Malaysian school learners. In these studies, the participants were ESL learners from primary schools (children aged 7-12 years old), such as those by B. C. Lee et al. (2019), M. C. L. Lee, Krishnamoorthy, and Rong (2019) and Meganathan et al. (2019). Educational policies involving English at the primary level have also attracted considerable attention among Malaysian scholars (e.g. Ali, Hamid, and Moni 2011; Azman 2016; Sabbah, Masood, and Iranmanesh 2013; Sulaiman, Mohd Ayub, and Sulaiman 2015; Yamat, Fisher, and Rich 2014; Yamat, Umar, and Mahmood 2014). These studies are no doubt, crucial in highlighting major issues in Malaysian educational landscapes. However, the empirical documentation of the pupils' English development, especially in terms of their lexical development, is critically lacking. 
For preschool children's L2 development, there are some studies conducted by several authors: Goh (2019), for instance, investigated the use of English in Malaysian preschools. The focus in Goh's study is, however, on the perception of teachers in using English as the language of instruction. In a study by Omar (2016), the author demonstrates that using Malay language to clarify some of the difficult English vocabulary using a read-aloud technique is effective for preschool children in the rural areas of Malaysia where exposure to English outside the class is limited. In another study, San and Abdullah (2014) found that the number of oral vocabulary Malaysian Chinese preschoolers possessed is a predictor of English language proficiency. There are some Malay-English bilingual acquisition studies by Salehuddin (2012), Mohamed Salleh $(2016,2017)$ and Mohamed Salleh et al. (2019, 2020a, 2021). These studies investigated how Malay-English bilingual children acquired English vocabulary and morphology in a primarily multilingual Malaysian setting. However, as stated by Razak (2014), studies that focus on the acquisition of English among Malaysian children are lacking and much of the literature on English language acquisition in Malaysia mostly involve single case studies. Studies by Salehuddin (2012), Mohamed Salleh (2016, 2017); Mohamed Salleh et al. $(2019,2020$ a, 2021) were also conducted on a single child's development, which limits the generalisability of the findings. Additionally, the studies were also conducted outside the Malaysian educational environment. Therefore, this paper bridges an objective gap by presenting the initial acquisition of English lexical forms among Malaysian preschoolers at the beginning of preschool instruction. This study also contributes to documenting the English lexico-morphological development of Malaysian preschool children at the earliest point in their schooling as well as offering a realistic reference for policymakers and educators.

\section{Methodology}

\section{The participants}

This study is part of a larger ongoing longitudinal FRGS (Fundamental Research Grant Scheme) project investigating the development of English lexicon and morphology among Malaysian preschoolers, using a new L2 intervention programme, the Developmentally Moderated Focus-on-Form instruction (DMFonF) (For more details on the DMFoNF approach, refer to Mohamed Salleh et al. 2020b). This paper analyses the first cross-sectional data set collected to define the initial stage of English acquisition amongst Malaysian preschoolers. Therefore, the principal aim of this paper is to present the baseline information of the children's English lexical production prior to the DMFonF intervention.

Ninety-nine children aged 5 and 6 years old (53 boys, 46 girls) from three public preschools under MOE participated in this study. Preschool classes at these preschools are built annexed to the public primary school building and the expenses are borne by MOE. These preschools cater to children who come from low-income families in the sub-urban, rural and remote areas. Before starting the research project, the researchers obtained permission to enter the school premises through https://eras.moe.gov.my/index.cfm. Once the formal letter was issued, the researchers met the principals and the teachers at each school to obtain their consent to allow the preschoolers at the respective school to join the research project. Consent from each parent/caretaker of the preschoolers was also obtained through a formal letter. According to the teachers, all the children speak Malay and understand Malay language instructions. The children were reported not to have any type of language impairment.

\section{Tasks and data collection procedure}

The preschoolers were audio- and video-recorded at their respective schools individually during the school period in one picture-naming elicitation session by the researchers. Before the recording 
session began, 'warming-up' activities, such as dancing, singing, playing, were organised to familiarise the children with the unfamiliar adults, i.e. the researchers. After the introductory session, each child, one at the time, was conveyed to a room provided by the teachers for the data collection procedure. The children were informed that the session was intended to look at their English vocabulary knowledge. However, if they did not know the English words for the pictures, they may describe the prompts in Malay.

In the course of the session, the children were asked to describe two types of picture tasks: (A) singular vs. plural prompts and (B) action-based prompts (see Figures 1 and 2). Similar tasks are often used in child language development research (e.g. Håkansson and Nettelbladt 1993; Medojevic 2014; Pienemann and Mackey 1993) to elicit specific linguistic structures. In fact, direct assessment such as picture identification and picture naming tasks are typically used to tap into the productive and receptive language domains (Haman, Łuniewska, and Pomiechowska 2015; Marchman and Dale 2018) as a means to gauge children's understanding and use of words. For task A, the researchers showed cards depicting animals, first a single animal followed by a card with several animals to elicit, e.g. cat versus cats. Thus, the target structures were the (usually default) singular form of a noun versus the same form with the suffix-s added to form a plural noun or NP. For task B, the researchers showed cards depicting actions (e.g. eating, crying) to elicit verbal forms. Throughout the session, if the child were quiet, the researchers would prompt the child by using simple encouragements, such as 'go on', 'yes', 'OK and?', 'Anything else?'. Verbal feedback from the researchers was minimised in order not to interfere with the child's description. Altogether, there were 792 minutes of recordings from the sessions, i.e. an average of 8.9 minutes per child.
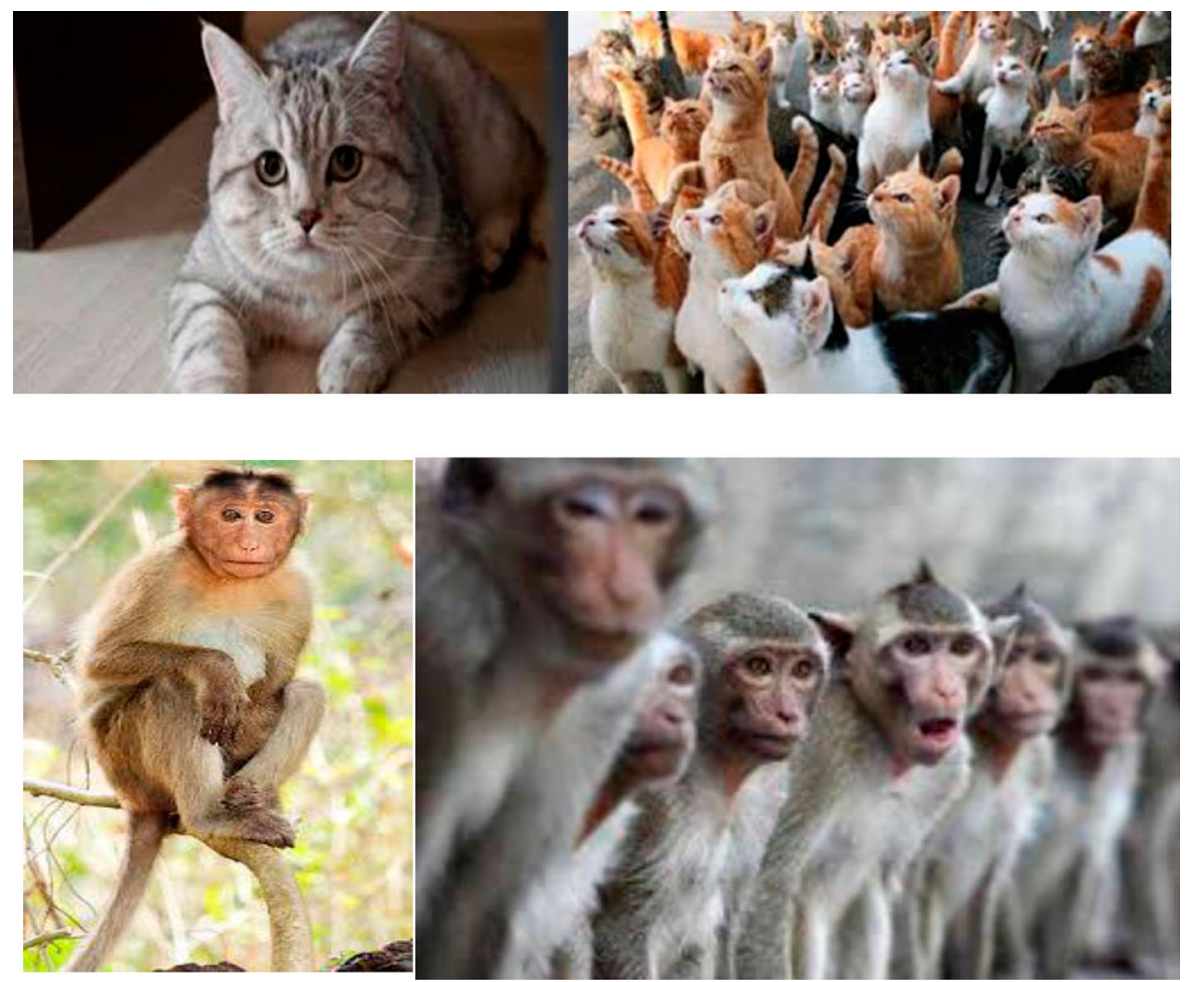

Figure 1. Example of singular and plural prompts shown to the preschoolers. 

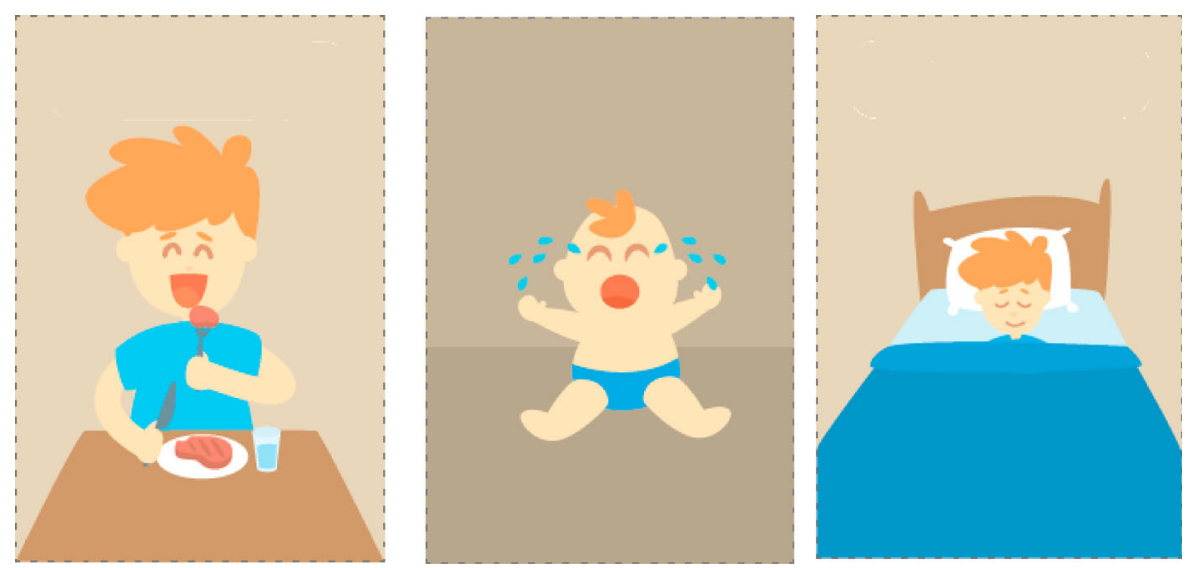

Figure 2. Example of action prompts shown to the preschoolers.

\section{Analytical procedure}

To answer the research question, ELAN (Sloetjes and Wittenburg 2008), a software to create annotations on video and audio resources, was used to transcribe the recordings. Due to the large number of recordings (99 separate audio and video recordings), five undergraduate research assistants, all linguistics major students who had received training for data transcription using ELAN, transcribed the recordings. After completing the transcriptions, the researchers cross-checked the whole transcription to ensure reliability. Discrepancies were then re-checked from the audio and video recordings. Following the guidelines set by Lanza (2004), with a slight modification to suit this study, several criteria were used in the analyses to interpret the forms in the children's utterances:

1. All the utterances were transcribed following the phonetic similarity with the adult lexical forms.

2. Echoes were not included in the analyses. An echo utterance is the child's output that repeats what has just been said by the researcher.

3. If a child produced an idiosyncratic form, the transcribers would refer to the situational settings and non-verbal communications captured in the video-recording to understand what the child meant.

In analysing the children's lexical output, the composition of different word categories and the cumulative number of word types in English and Malay produced in the recording sessions were conducted using KWIC (Key Word in Context), a concordance software that helps to generate an index of the lexical types produced indicating the number of occurrences (tokens) for each different word type in the data as well as providing a full context in which the token occurred. This would often help interpret the intended meaning of a form via its immediate context. The frequencies of the tokens produced by the children in English and Malay were also analysed using KWIC. Although this paper aims to describe, primarily, the English lexical forms produced by the preschoolers, Malay and mixed utterances were also included in the analyses. The inclusion of English and Malay utterances would allow gaining a fuller picture of the children's overall language development.

\section{Results and discussion}

This section presents the results of the investigation based on the research question posed earlier: What English lexical forms do Malaysian preschoolers produce at the beginning of formal instruction? 


\section{Lexical forms produced in the elicitation task}

Before proceeding to the lexical analyses, the children's language choice will be discussed first. Based on observation from the recording sessions, all the children in the study comprehended the English instructions and demonstrated greater receptive knowledge than their production might show. The discrepant performance between productive and receptive skills in early L2 has been addressed by other bilingual acquisition researchers such as, e.g. Håkansson (2019), who found that Swedish-English preschoolers understood the English instructions but responded to the task in Swedish. Similarly, the children in this study understood the English instruction but their responses varied in terms of language choice.

Figure 3 illustrates the children's languages used to respond to the noun and verb elicitation tasks. There were three patterns among the children to name the objects or actions in the pictures: (1) English only; (2) both English and Malay and; (3) Malay only. We found an important difference between the two lexical categories, the noun, elicited by Task 1 , and the verb, elicited by Task 2 . As for the noun category, 16 children out of 99 participants produced all the nouns in English. Thirtyfour children used either English or Malay nouns to describe the prompts i.e. they produced mixed responses, and 49 of the children (i.e. 49\%) described all the prompts using Malay nouns only. As for the verb category, English productions were highly limited. Only 4 children (i.e. $4 \%$ ) used English only to describe the actions in the pictures, and 14 children (i.e. 14\%) used both Malay and English verbs. The remaining 81 children (i.e. 82\%) used Malay only. This means that about four out of five children resorted to Malay verbs to describe the prompts. The results reveal that these preschoolers can produce more English nouns than verbs at the onset of kindergarten schooling. The verb category, however, is crucial in language development since the verb category drives syntactic structures.

What are the English lexical items that the children know at this point? We first look at the lexical categories, types and tokens, produced by the children in the session. Table 1 summarises the children's production of the main lexical categories. The listing of lexical categories is based on Kroeger's (2005) listing of major lexical categories and Razak et al.'s (2016) on Malay grammar.

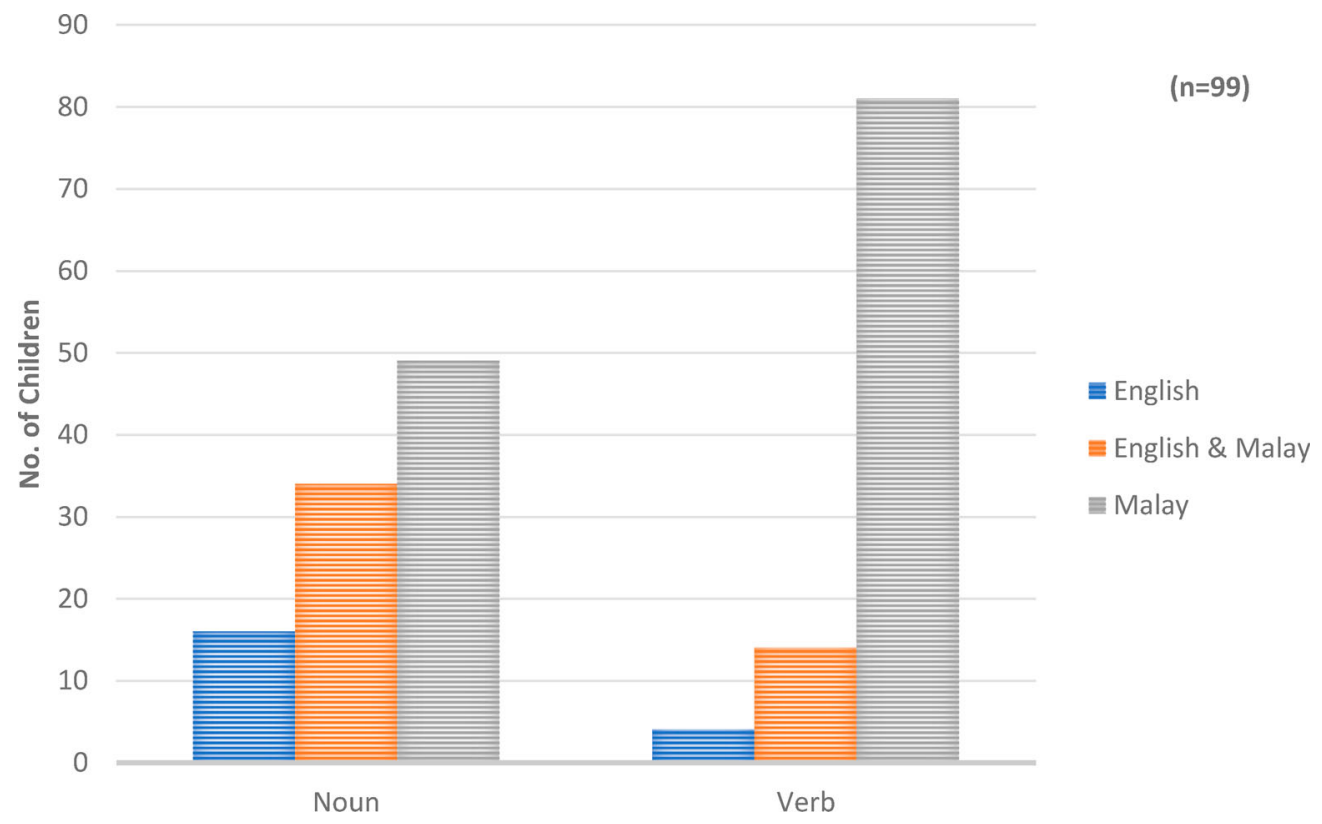

Figure 3. The preschoolers' production in the noun and verb elicitation tasks. 
The total types and tokens in each language do not exhaustively indicate the number of lexical items the children know but rather the lexical items the children uttered in the recording sessions.

In English, noun was the most productive lexical form followed by verbs. Other categories were not elicited but, remarkably, were spontaneously produced by the children. Adjectives were the most frequent of these spontaneous categories but a variety of other minor categories and expressions were produced both in English and, less surprisingly, Malay. Previous studies on L1 English monolingual children have shown that nouns are the earliest vocabulary to be acquired (Clark 1979; Dromi 1987; Gentner 1982). Gentner (1982) called this linguistic phenomenon noun-bias and regarded this as universal across cultures. She cited findings from several languages (English, German, Turkish) in which the children's early vocabulary was primarily centred on nominals. Regarding English, Gentner and Boroditsky (2001) state that it is a 'noun-dominant' language, so the substantial number of English nouns compared to the English verbs produced by the preschoolers in Table 1 corroborate the 'noun-dominance' nature of the English language. In the Malaysian context, a study by Mohamed Salleh et al. (2020a) on Malay-English bilingual primary school children also found that when speaking English, the children produced many more English nouns compared to other lexical categories in the language.

Other researchers, however, have questioned the assumed universality of the noun bias. Findings from the L1 acquisition of Mandarin (Tardif 1996) and Korean (Gopnik and Choi 1995) show that verb, rather than noun, is the most salient lexical category in the children's early vocabulary. Likewise, findings from bilingual acquisition studies such as Malay-English (Mohamed Salleh (2017), Japanese-English (Itani-Adams 2013) and Filipino-English (Lucas and Bernardo 2008) show that verbs are predominant among the children's lexical items in Malay, Japanese and Filipino respectively while nouns are predominant in their English lexical constructions. In this context, it is interesting to find that the preschoolers in our study were found to produce, overall, more Malay verbs than nouns. Thus, Table 1 shows that children produced $6.5 \%$ higher verb types and $14.7 \%$ higher verb tokens in Malay than in English. This could be attributed to the character of Malay typology which, unlike English, allows subject and object drop (Razak et al. 2016), making verbs relatively more frequent in Malay speakers' utterances. Thus, based on the recorded preschoolers' output the overall results replicate earlier bilingual acquisition studies. Noun-bias is only evident in the children's English vocabulary, not in their Malay.

Table 2 ranks the most frequent English and Malay noun types produced by the preschoolers when describing the singular prompts shown by the researchers. The number in the bracket indicates the total tokens.

In English, the singular-plural distinction is a grammatical feature of the language e.g. the default form of noun (cat) vs. noun + suffix -s (cats). On the other hand, the singular-plural distinction is ambiguous in Malay, where nouns can either be interpreted as singular or plural (Sew 2007). In the corpus, we found that all the children used the default form of nouns in English and Malay when describing singular prompts. However, due to the different singular-plural features between English and Malay, it is difficult to interpret whether the children were actually using the default form to denote singular entities. Interestingly, when describing the plural targets, the children used various strategies such as monkeys, many gorilla and banyak ayam 'many chicken'. Table 3 shows examples

Table 1. Lexical categories, types and tokens in English and Malay.

\begin{tabular}{llll}
\hline Lexical categories & English types/tokens & Malay types/tokens & \multicolumn{1}{c}{ Examples from the corpus } \\
\hline Noun & $44 / 379$ & $62 / 769$ & cat, tiger, ayam 'chicken' \\
Verb & $22 / 100$ & $66 / 882$ & eat, sit, makan 'eat', tidur 'sleep' \\
Adjective & $8 / 39$ & $12 / 64$ & pink, blue, biru'blue', banyak 'many' \\
Adverb & 0 & $2 / 2$ & saja 'only', lagi 'more' \\
Others & $5 / 27$ & $11 / 315$ & yes, no, my, you, saya 'I', dia 'he/she' \\
Total & $79 / 545$ & $153 / 2032$ & \\
\hline
\end{tabular}


Table 2. Most frequent nouns produced by the preschoolers (singular prompts).

\begin{tabular}{lc}
\hline English & \multicolumn{1}{c}{ Malay } \\
\hline Monkey (41) & Ayam 'chicken' (80) \\
Cat (33) & Monyet 'monkey' (67) \\
Tiger(29) & Kucing 'cat' (63) \\
Cow (23) & Harimau 'tiger' (58) \\
Chicken (21) & Lembu 'cow' (58) \\
Lion (11) & Buku 'book' (10) \\
Bird (2) & Bunga 'flower' (9) \\
\hline
\end{tabular}

from the data of the most frequent nouns produced by the participants in response to plural prompts. The number in brackets shows their frequency in the data.

In expressing plurals, the children generally produced default forms in English and Malay (e.g. cat, kucing 'cat'). There were several occurrences of English suffix-s at the lexical level (e.g. monkeys, chickens, cats), followed by quantifiers ten thousand and many paired with the default form (e.g. ten thousand cat, many gorilla). This English acquisition structure (default form $>$ suffix $-\mathrm{s}>$ quantifier + default form) was also found in English L1 acquisition research by Clark and Nikitina (2009). They found that when pluralising nouns in English, the monolingual English-speaking children opted for the default form. In their study, plural suffix-s was found in very few items, and some children produced quantifier+ default form (e.g. many blanket).

In Malay, though nouns can be interpreted as either singular or plural, there are several linguistic structures to encode plurality, such as reduplication (e.g. kucing-kucing 'cats'), numeral classifiers (e.g. tiga ekor kucing 'three tail cat') and quantifiers (e.g. banyak kucing 'many cat') (Hassan 2006; Salehuddin and Winskel 2009; Sew 2007; Tadmor 2009). Interestingly, there were no reduplicative utterances produced by the children to express plurals in Malay except for kawan-kawan 'friends', which the children used as a quantifier and paired with Malay nouns (e.g. kawankawan kucing 'cat's friends, kawan-kawan kambing 'goat's friends'). There was also the use of quantifiers banyak 'many' with Malay nouns (e.g. banyak ayam 'many chicken', banyak lembu 'many cow'). In Malay-English bilingual acquisition studies by Mohamed Salleh (2017) and Mohamed Salleh et al. (2016, 2019, 2021), reduplication was one of the plural marking strategies the Malay-English child acquired later in development. Since we have yet to see Malay reduplication as a marker of plurals in our data, we postulate that reduplication, as a mechanism for marking plural number, may actually emerge later in children's development. It is entirely possible, of

Table 3. Most frequent nouns produced by the preschoolers (plural prompts).

\begin{tabular}{|c|c|c|c|c|}
\hline \multicolumn{3}{|r|}{ English } & \multicolumn{2}{|r|}{ Malay } \\
\hline $\begin{array}{l}\text { Default } \\
\text { form }\end{array}$ & Suffix $-s$ & Quantifier + default form & Default form & Quantifier + default form \\
\hline Cat (39) & $\begin{array}{l}\text { Monkeys } \\
\text { (3) }\end{array}$ & $\begin{array}{l}\text { Ten thousand + noun (e.g. ten } \\
\text { thousand cat, ten thousand } \\
\text { chicken) (2) }\end{array}$ & $\begin{array}{l}\text { Harimau } \\
\text { 'tiger (35) }\end{array}$ & $\begin{array}{l}\text { Kawan/kawan-kawan 'friend/friends'+ noun (e.g. } \\
\text { kawan harimau 'tiger's friend', kawan lembu } \\
\text { 'cow's friend', kawan-kawan kambing 'goat's } \\
\text { friend', kawan-kawan kucing 'cat's friends') (13) }\end{array}$ \\
\hline Tiger (29) & $\begin{array}{l}\text { Chickens } \\
\text { (1) }\end{array}$ & $\begin{array}{l}\text { Many + noun (e.g. many gorilla) } \\
\text { (1) }\end{array}$ & $\begin{array}{l}\text { Ayam } \\
\text { 'chicken' } \\
\text { (29) }\end{array}$ & $\begin{array}{l}\text { Banyak 'many' + noun (e.g. banyak ayam 'many } \\
\text { chicken', banyak harimau 'many tiger', banyak } \\
\text { lembu 'many cow') (11) }\end{array}$ \\
\hline $\begin{array}{l}\text { Monkey } \\
\text { (28) }\end{array}$ & Cats (1) & & $\begin{array}{l}\text { Lembu 'cow' } \\
\text { (25) }\end{array}$ & \\
\hline Cow (18) & & & $\begin{array}{l}\text { Monyet } \\
\text { 'monkey' } \\
(23)\end{array}$ & \\
\hline $\begin{array}{c}\text { Chicken } \\
\text { (17) }\end{array}$ & & & $\begin{array}{l}\text { Kucing 'cat' } \\
\text { (20) }\end{array}$ & \\
\hline Lion (8) & & & Kambing 'goat' & \\
\hline Gorilla (6) & & & Kerbau 'bull'(3) & \\
\hline
\end{tabular}


course, that the context of the elicitation session might have played a role in the lack of reduplication in our data.

Now we turn to the verbs produced by the children. Table 4 ranks the five most frequent verb forms produced by the preschoolers in response to verb elicitation prompts.

As discussed earlier, more than half of the preschoolers used only the Malay language to describe the action prompts (see Figure 3). This explains, to some extent, the high number of Malay verb tokens as compared to the English verbs. The English verb forms found in the corpus are the default form (i.e. sleep, eat, cry) as well as the V+ -ing (i.e. sleeping, eating, crying). The children did not produce the English grammatical form with auxiliaries such as be $+\mathrm{V}$-ing (i.e. is/are/am/was sleeping) at this point in time. The early marking of -ing on verb in English L2, according to Johnston $(1997,2000)$ functions as a categorical marker on verbs (differentiating them from nouns) rather than expressing progressive aspect. The data in this study also confirms that the -ing marker is the first 'lexical' morpheme to appear in learners of English in terms of the Processability Theory schedule as found in Mohamed Salleh et al. (2020a).

In Malay, the verb is an obligatory element in a clause (Razak et al. 2016). It is possible to have a clause without a subject (e.g. makan nasi 'eat rice') but not a clause without a verb (e.g. ${ }^{\star}$ nasi 'rice'). This pro-drop phenomenon is manifested in the children's utterances of Malay verbs in Table 4; when describing the action prompts, the children simply produced the verb (e.g. makan 'eat', tidur 'sleep') and some children produced the Aspect marker tengah $+\mathrm{V}$ (e.g. tengah makan 'ASP eat'). Malay verb is not inflected for tense and the progressivity of action is encoded by the use of aspect markers sedang/tengah (Razak et al. 2016; Sew 2016). In the data, the children used aspect tengah to indicate progressivity.

From the analyses of the preschoolers' lexical production in response to the elicitation tasks it is apparent that, collectively, the children possessed a limited range of productive abilities in English at the beginning of formal instruction. Hoff (2014) proposes that word learning is not a one-to-one mapping process between the concepts and the lexicon; sometimes, children have concepts for which there is no word in the language and hence, they invent words to fill the lexical gap. For bilingual/multilingual children, such as the preschoolers in this study, their strategy to bridge the lexical gaps in English is by accessing the lexical resources in the Malay language. The lexical-gap hypothesis (Quay 1995) does not necessarily imply that bilingual children have a single lexicon for both languages, as some researchers claim (see, for example, Volterra and Taeschner 1978). Children were, in fact, trying hard to use the language in context but may have possessed a limited vocabulary in English and possibly even in their Malay.

Another issue that we wish to discuss regarding the findings is the sociolinguistic context and the researchers' bilingual identity. Prior to the recording session, the researchers did communicate with the teachers in Malay in front of the preschoolers. Therefore, though the researchers communicated in English during the recording session, the fact that the children were aware of the researchers' bilingual identity might have possibly contributed to the production of codeswitching utterances in some children. Lanza (2000) states that though adult interlocutors may use one language with the bilingual child, 'an indication of comprehension of the other language may contribute to bilingual context' (235). This could be the case in our study; the sociolinguistic factor of the context might have activated the psycholinguistic aspect of the bilingual language mode (Lanza 2004).

Table 4. English and Malay verb forms produced by the preschoolers.

\begin{tabular}{llll}
\hline \multicolumn{2}{c}{ English verbs } & \multicolumn{2}{c}{ Malay verbs } \\
\cline { 1 - 2 } Default form & \multicolumn{1}{c}{ V+ -ing } & & Default form \\
\hline Sleep (15) & Sleeping (10) & Makan 'eat' (85) & Tengah terbang 'flying' (15) \\
Eat (12) & Swimming (6) & Tidur 'sleep' (79) & Tengah duduk 'sitting' (14) \\
Sit (7) & Crying (3) & Baca 'read' (77) & Tengah makan 'eating' (12) \\
Cry (4) & Flying (3) & Duduk 'sit' (75) & Tengah baca 'reading' (10) \\
Swim (4) & Drawing (2) & Terbang 'fly' (66) & Tengah tidur 'sleeping' (9) \\
\hline
\end{tabular}


Therefore, it is difficult to conclude whether the children who resorted to Malay utterances do not know the words in English. Perhaps, they were simply codeswitching or codemixing due to the sociolinguistic context and the researchers' bilingual identity.

\section{Conclusion}

This paper reports on 99 Malay-English bilingual preschool children's English baseline in terms of the production of lexical forms at the beginning of formal English instruction at school. The findings show that at the beginning of formal instruction, the preschoolers displayed a limited range of productive skills in their L2 vocabulary with some of the children producing the early stages of morphological development such as some categorial marking of verbs $(\mathrm{V}$-ing) and plural $(\mathrm{N}-s)$ number in nouns. In any case, at that point, all of the children already display a range of receptive skills in English greater than their productive skills. Knowing that the children possessed some receptive skills in English upon their preschool enrolment, we suggest that schools provide a communicative context in the classroom for children to use the language. Providing a platform for the preschoolers to be addressed in, and consistently exposed to, English, and encouraging them to use the language would benefit the children's L2 acquisition, because the learner output itself has a role to play in language acquisition (Swain 1985). Some limitations of this study include its crosssectional nature. A longitudinal design that followed the same children over their preschool education would allow development in their lexical skills to be measured over time. As mentioned earlier, this paper reports the first of an ongoing longitudinal investigation on the preschoolers' development of English lexicon and morphology using the DMFonF approach. Therefore, further development regarding the children's acquisition over a longer period will hopefully become available in future publications issuing from this project.

\section{Disclosure statement}

No potential conflict of interest was reported by the author(s).

\section{Funding}

This work was supported by the Fundamental Research Grant Scheme, Ministry of Higher Education, Malaysia [Grant Number FRGS/1/2019/SSI01/UIAM/03/1].

\section{References}

Ahmad, Z. 2005. The Phonology-Morphology Interface in Malay: An Optimality Theoretic Account. Canberra, Australia: Pacific Linguistics.

Ali, N. L., M. O. Hamid, and K. Moni. 2011. "English in Primary Education in Malaysia: Policies, Outcomes and Stakeholders' Lived Experiences.” Current Issues in Language Planning 12 (2): 147-166. doi:10.1080/14664208. 2011.584371.

Arshad, M. A., and V. Subramaniam. 2006. "Pemerolehan morfologi dan sintaksis dalam kalangan kanak-kanak melayu pada peringkat menjelang tatabahasa [The Acquisition of Morphology and Syntax Among Malay Children at the Pre-language Stage].” Jurnal Dewan 6: 112-120.

Azman, H. 2009. "English in 1Malaysia: A Paradox in Rural Pluri-Literacy Practices.” Akademika 76: $27-41$.

Azman, H. 2016. "Implementation and Challenges of English Language Education Reform in Malaysian Primary Schools." 3L: The Southeast Asian Journal of English Language Studies 22 (3): 65-78.

Bresnan, J. 2001. Lexical-functional Syntax. Oxford: Blackwell.

Che Musa, N., Y. L. Khoo, and H. Azman. 2012. "Exploring English Language Learning and Teaching in Malaysia." Gema Online Journal of Language Studies 12 (1): 35-51.

Clark, E. 1979. “Building a Vocabulary: Words for Objects, Actions and Relations.” In Language Acquisition, edited by P. Fletcher and M. Garman, 149-160. Cambridge: Cambridge University Press.

Clark, E. V., and T. V. Nikitina. 2009. “One vs More than One: Antecedents to Plural Marking in Early Language Acquisition.” Linguistics 47 (1): 103-139. 
Dromi, E. 1987. Early Lexical Development. Cambridge: Cambridge University Press.

Gentner, D. 1982. "Why Nouns are Learned Before Verbs: Linguistic Relativity Versus Natural Partitioning." In Language Development: Language, Thought, and Culture, Vol. 2, edited by S. A. Kuczaj, 301-334. Hillsdale: Lawrence Erlbaum Associates.

Gentner, D., and L. Boroditsky. 2001. "Individuation, Relativity, and Early Word Learning.” In Language Acquisition and Conceptual Development, edited by M. Bowerman and S. C. Levinson, 215-256. Cambridge: Cambridge University Press.

Gill, S. K. 2014. Language Policy Challenges in Multi-Ethnic Malaysia. New York: Springer.

Goh, P. S. 2019. "Preschool Teachers' Perspectives on Using English Language to Teach." GEMA Online Journal of Language Studies 19 (4): 346-362.

Gopnik, A., and S. Choi. 1995. "Names, Relational Words, and Cognitive Development in English and Korean Speakers: Nouns are not Always Learned Before Verbs.” In Beyond Names for Things: Young Children's Acquisition of Verbs, edited by M. Tomasello and W. E. Merriman, 83-90. New Jersey: Erlbaum.

Håkansson, G. 2019. "How Much English do Children Know Before They are Exposed to Instruction?" In Teachability and Learnability Across Languages, edited by R. Arntzen, G. Håkansson, A. Hjelde, and J.-U. Keßler, 28-49. Amsterdam: John Benjamins.

Håkansson, G., and U. Nettelbladt. 1993. "Developmental Sequences in L1 (Normal and Impaired) and L2 Acquisition of Swedish Syntax." International Journal of Applied Linguistics 3 (2): 131-155. doi:10.1111/j.14734192.1993.tb00047.x.

Haman, E., M. Łuniewska, and B. Pomiechowska. 2015. "Designing Cross-Linguistic Lexical Tasks (CLTs) for Bilingual Preschool Children.” In Assessing Multilingual Children: Disentangling Bilingualism from Language Impairment, edited by Armon-Lotem Sharon, Jan De Jong, and Natalia Meir, 196-240. Bristol: Multilingual Matters.

Hassan, A. 2006. Morfologi: siri pengajaran dan pembelajaran bahasa Melayu [Morphology: Malay Language Teaching and Learning]. Kuala Lumpur: PTS.

Hoff, E. 2014. Language Development. 5th ed. Belmont: Wadsworth Cengage Learning.

Isai, K., M. Govindasamy, R. Ramalingam, H. Ching, and M. Kausalya. 2020. "Preparedness for the World of Work Among Malaysian Diploma Students in a Local Institution.” Malaysian Journal of Social Sciences and Humanities (MJSSH 5 (4): 56-70.

Itani-Adams, Y. 2013. One Child and Two Languages: Acquisition of Japanese and English as Bilingual First Languages. Munchen: Lincolm.

Johnston, M. 1997. Development and variation in learner language. (Unpublished PhD thesis). Australian National University, Canberra.

Johnston, M. 2000. Stages of Development for English as a Second Language. New South Wales: Language Australia.

Kaplan, R. M., and J. Bresnan. 1982. "Lexical-functional Grammar: A Formal System for Grammatical Representation.” In The Mental Representation of Grammatical Relations, edited by J. Bresnan, $173-281$. Cambridge: MIT Press.

Kroeger, P. R. 2005. Analysing Grammar: An Introduction. New York: Cambridge University Press.

Lanza, E. 2000. "Concluding Remarks: Language Contact--A Dilemma for the Bilingual Child or for the Linguist." In Cross-linguistic Structures in Simultaneous Bilingualism, edited by S. Dopke, 227-245. Philadelphia: John Benjamins.

Lanza, E. 2004. Language Mixing in Infant Bilingualism: A Sociolinguistic Perspective. New York: Oxford University Press.

Lee, M. C. L., K. Krishnamoorthy, and Y. J. Rong. 2019. “The Role of Negotiated Interaction in L2 Vocabulary Acquisition among Primary ESL Learners.” 3L: The Southeast Asian Journal of English Language Studies 25 (2): 1-21.

Lee, B. C., A. Pandian, S. Rethinasamy, and D. A. I. Tan. 2019. "Effects of PWIM in the ESL Classroom: Vocabulary Knowledge Development Among Primary Malaysian Learners.” 3L: The Southeast Asian Journal of English Language Studies 25 (4): 179-197.

Lucas, R. I., and A. B. Bernardo. 2008. "Exploring Noun Bias in Filipino-English Bilingual Children." The Journal of Genetic Psychology 169 (2): 149-163. doi:10.3200/gntp.169.2.149-164.

Marchman, V., and E. Bates. 1994. "Continuity in Lexical and Morphological Development: A Test of the Critical Mass Hypothesis." Journal of Child Language 21: 339-366.

Marchman, V. A., and P. S. Dale. 2018. "Assessing Receptive and Expressive Vocabulary in Child Language." In Research Methods in Psycholinguistics and the Neurobiology of Language: A Practical Guide, edited by A. N. M. de Groot and P. Hagoort, 40-66. New Jersey: Wiley Blackwell.

Medojevic, L. 2014. The effect of the first year of schooling on bilingual language development: A study of second and third generation Serbian-Australian 5-year-old bilingual children from a Processability perspective. (Unpublished PhD thesis). Western Sydney University, Australia. 
Meganathan, P. M., Y. N. Thai, S. Paramasivam, and I. Jalaluddin. 2019. "Incidental and Intentional Learning of Vocabulary among Young ESL Learners.” 3L: The Southeast Asian Journal of English Language Studies 25 (4): 51-67.

Ministry of Education. 2013. Malaysia Education Blueprint 2013-2025 (Preschool to Post Secondary Education). Putrajaya, Malaysia: Ministry of Education Malaysia.

Ministry of Education. 2016. National Standard Preschool Curriculum. Putrajaya: Ministry of Education Malaysia.

Mohamad Noor, H. N. 2002. "Pemerolehan bahasa kanak-kanak melayu: satu kajian kes [Language Acquisition of a Malay Child: A Case Study].” Jurnal Dewan 2: 465-489.

Mohamed Salleh, Rabiah Tul Adawiyah. 2017. Bilingual First Language Acquisition in Malay and English: A morphological and suprasegmental study in the development of plural expressions in a bilingual child. (PhD thesis, Western Sydney University Australia). ResearchDirect Library. https://researchdirect.westernsydney.edu.au/ islandora/object/uws\%3A46378.

Mohamed Salleh, Rabiah Tul Adawiyah, Bruno Di Biase, and Satomi Kawaguchi. 2021. "Lexical and morphological development: A case study of Malay English bilingual first language acquisition." Psychology of Language and Communication 25 (1): 29-61.

Mohamed Salleh, Rabiah Tul Adawiyah, Satomi Kawaguchi, and Bruno Di Biase. 2019. "A case study on the acquisition of plurality in a bilingual Malay-English context-bound child." GEMA Online Journal of Language Studies 19 (3): $22-42$.

Mohamed Salleh, Rabiah Tul Adawiyah, Maskanah Lotfie, Md. Zamin Ainul Azmin, Bruno Di Biase, and Satomi Kawaguchi. 2020b. "Towards a new framework of English language learning in Malaysian preschools." Southeast Asia Early Childhood Journal 9 (2): 144-154.

Mohd Zin, Z., W. B. Eng, and S. Rafik-Galea. 2014. "Critical Reading Ability and its Relation to L2 Proficiency of Malaysian ESL Learners.” 3L: The Southeast Asian Journal of English Language Studies 20 (2): 43-54.

Moyle, M. J., S. E. Weismer, J. L. Evans, and M. J. Lindstrom. 2007. "Longitudinal Relationships Between Lexical and Grammatical Development in Typical and Late-Talking Children.” Journal of Speech, Language, and Hearing Research 50: 508-528.

Mustafa, L. M., and M. N. A. Azman. 2013. "Preschool Education in Malaysia: Emerging Trends and Implications for the Future." American Journal of Economics 3 (6): 347-351.

Omar, A. 1988. "Faktor Psikolinguistik dan sosiolinguistik dalam pelajaran dan pemelajaran bahasa [Psycholinguistic and Sociolinguistic Factors in Learning and Acquiring Language]." Jurnal Dewan 32: 5-17.

Omar, A. 2016. "Read-Aloud Technique to Enhance Pre-School Children's Vocabulary in a Rural School in Malaysia.” International Journal of Early Childhood Education Care 5: 17-27.

Pandian, A. 2002. "English Language Teaching in Malaysia Today.” Asia-Pacific Journal of Education 22 (2): 35-52.

Pienemann, M., and A. Mackey. 1993. “An Empirical Study of Children's ESL Development and Rapid Profile.” In ESL Development: Language and Literacy in Schools, edited by P. McKay, 115-259. Canberra: Commonwealth of Australia and National Languages and Literacy Institute of Australia.

Quay, S. 1995. “The Bilingual Lexicon: Implications for Studies of Language Choice.” Journal of Child Language 22 (2): 369-387. doi:10.1017/S0305000900009831.

Mohamed Salleh Rabiah Tul Adawiyah, Bruno Di Biase, and Ramlan Wan Nur Madiha. 2020a. "The acquisition of English grammar among Malay-English bilingual primary school children.” GEMA Online Journal of Language Studies 20 (4): 166-185.

Mohamed Salleh Rabiah Tul Adawiyah, Satomi Kawaguchi, Caroline Jones, and Bruno Di Biase. 2016. "The development of plural expressions in a Malay-English bilingual child." Asiatic 10 (2): 60-81.

Razak, R. A. 2014. "Studies on the Acquisition of Morphology and Syntax Among Malay Children in Malaysia: Issues, Challenges and Needs." In South and Southeast Asian Psycholinguistics, edited by H. Winskel and P. Padakannaya, 133-144. Cambridge: Cambridge University Press.

Razak, R. A., L. Jin, H. W. Lim, and M. A. Aziz. 2016. “Profiling Malay Children's Syntactic Development: A MalayLARSP.” In Profiling Grammar: More Languages of LARSP, edited by D. Crystal, J. M. Ball, and P. Fletcher, 135169. Bristol, UK: Multilingual Matters.

Sabbah, M., M. Masood, and M. Iranmanesh. 2013. "Effects of Graphic Novels on Reading Comprehension in Malaysian Year 5 Students." Journal of Graphic Novels and Comics 4 (1): 146-160. doi:10.1080/21504857.2012. 757246.

Salehuddin, K. 2012. “The Acquisition of English Negative Constructions by a Malay Bilingual Child.” 3L: The Southeast Asian Journal of English Language Studies 18 (4): 181-191.

Salehuddin, K., and H. Winskel. 2009. “An Investigation Into Malay Numeral Classifier Acquisition Through an Elicited Production Task.” First Language 29 (3): 289-311. doi:10.1177/0142723709103187.

San, P. H., and A. C. Abdullah. 2014. "Oral Vocabulary as a Predictor of English Language Proficiency among Malaysian Chinese Preschool Children.” 3L: The Southeast Asian Journal of English Language Studies 20 (1): 143-156.

Sansavini, A., A. Guarini, R. Alessandroni, G. Faldella, G. Giovanelli, and G. Salvioli. 2006. "Early Relations Between Lexical and Grammatical Development in Very Immature Italian Preterms." Journal of Child Language 33: $199-216$. 
Sarudin, I., Z. Mohd Noor, A. M. Zubairi, T. B. Tunku Ahmad, and M. S. Nordin. 2013. "Needs Assessment of Workplace English and Malaysian Graduates' English Language Competency.” World Applied Sciences Journal 21: 88-94.

Sew, J. W. 2007. Reduplicating Nouns and Verbs in Malay: A Conceptual Analysis. Kuala Lumpur: University of Malaya press.

Sew, J. W. 2016. “Aspect in Malay Verbs: Realigning Time and Volition to Malay Events.” Issues in Language Studies 5 (1): 44-63.

Simanjutak, M. 1990. "Pertumbuhan dan perkembangan bahasa kanak-kanak [The Growth and Development of Child Language].” Jurnal Dewan 34: 692-704.

Sloetjes, H., and P. Wittenburg. 2008. ELAN. Version 4.9.3. http://tla.mpi.nl/tools/tla-tools/elan/.

Sulaiman, T., A. F. Mohd Ayub, and S. Sulaiman. 2015. "Curriculum Change in English Language Curriculum Advocates Higher Order Thinking Skills and Standards-Based Assessments in Malaysian Primary Schools.” Mediterranean Journal of Social Sciences 6 (2): 494-500.

Swain, M. 1985. "Communicative Competence: Some Roles of Comprehensible Input and Comprehensible Output in its Development." In Input in Second Language Acquisition, edited by S. Gass and C. Maddrn, $235-253$. Cambridge: Newbury House.

Tadmor, U. 2009. “Malay-Indonesian.” In The World's Major Languages. 2nd ed., edited by B. Comrie, 791-819. London: Routledge.

Tardif, T. 1996. "Nouns are not Always Learned Before Verbs: Evidence from Mandarin Speakers' Early Vocabularies.” Developmental Psychology 32: 492-504.

Ting, S.-H., E. Marzuki, K.-M. Chuah, J. Misieng, and J. Jerome. 2017. "Employers' Views on the Importance of English Proficiency and Communication Skill for Employability in Malaysia." Indonesian Journal of Applied Linguistics 7 (2): 315-327.

Turiman, S., N. Abdullah, and N. Mohd Noor. 2018. "Spoken Metadiscourse in Malaysian ESL Job Interviews." GEMA Online Journal of Language Studies 18: 3.

Volterra, V., and T. Taeschner. 1978. "The Acquisition and Development of Language by Bilingual Children." Journal of Child Language 5: 311-326.

Wilkins, D. 1972. Linguistics in Language Teaching. Cambridge: MIT Press.

Yamat, H., R. Fisher, and S. Rich. 2014. "Revisiting English Language Learning among Malaysian Children." Asian Social Science 10 (3): 174-180.

Yamat, H., N. F. M. Umar, and M. I. Mahmood. 2014. "Upholding the Malay Language and Strengthening the English Language Policy: An Education Reform.” International Education Studies 7 (13): 197-205.

Zainuddin, S. Z., S. Pillai, F. P. Dumanig, and A. Phillip. 2018. "English Language and Graduate Employability." Education + Training 61 (1): 79-93. 